IQTISHODUNA

Vol. 17 (1), 2021

P-ISSN: 1829-524X, E-ISSN: 2614-3437

\title{
Implementation of The Islamicity Performance Index Approach to Analysis of Sharia Banking Financial Performance In Indonesia
}

\author{
Naning Fatmawatie \\ IAIN Kediri, Indonesia \\ E-mail: naningfat@gmail.com
}

\begin{abstract}
Islamic bank performance appraisal uses criteria with specific characteristics, namely the Islamicity Performance Index. This study aims to analyze the development of the financial performance of Islamic Commercial Banks in Indonesia. This type of research is descriptive quantitative research. Sampling using purposive sampling. The analysis technique uses non-statistical quantitative methods. This study indicates that the PSR tends to increase, and the best is Bank Mega Syariah. The best ZPR of BNI Syariah. BRI Syariah's best EDR Qard, for the best EDR Employees Bank Mega Syariah, for the best EDR Dividend BSM. BSM's best EDR net profit. For WD-Employee, Mega Syariah Bank's best ratios and for income syariah VS Non income syariah are all very good. This research implies that it can contribute to Islamic Commercial Banks to evaluate their performance primarily for the Zakat Performance Ratio so that the role of Islamic social banks will be better.
\end{abstract}

Keywords: Islamic, Performance, Index, Performance, Bank, Sharia

\begin{abstract}
Abstrak: Penilaian kinerja bank syariah menggunakan kriteria dengan karakteristik tertentu yaitu Islamicity Performance Index. Tujuan penelitian ini untuk menganalisis perkembangan kinerja keuangan Bank Umum Syariah di Indonesia menggunakan pendekatan Islamicity Performance Index. Jenis penelitian ini adalah penelitian diskriptif kuantitatif. Pengambilan sampel menggunakan purposive sampling. Sampel penelitian ini 6 Bank Umum Syariah. Tekhnik analisa menggunakan metode kuantitatif non statistic. Hasil penelitian menunjukkan bahwa Profit Sharing Ratio cenderung meningkat dan yang terbaik Bank Mega Syariah. Zakat Performace Ratio terbaik BNI Syariah. Equitable Distribution Ratio Qard terbaik BRI Syariah, untuk EDR Employess yang terbaik Bank Mega Syariah, untuk EDR Devidend yang terbaik BSM. Laba bersih EDR terbaik BSM. Untuk Directors-Employee Walfare, rasio terbaik Bank Mega Syariah dan untuk Pendapatan Syariah VS Pendapatan Non-Islam semuanya sangat baik. Implikasi penelitian ini dapat memberikan kontribus pada Bank Umum Syariah agar mengevaluasi kinerjanya utamanya untuk Zakat Performance Ratio, sehingga peran social bank syariah akan lebih baik.
\end{abstract}

Kata Kunci: Islamic, Performance, Indeks, Kinerja, Bank, Syariah 


\section{How to Cite:}

Fatmawatie. N. (2020). Implementation of The Islamicity Performance Index Approach to Analysis of Sharia Banking Financial Performance In Indonesia. Iqtishoduna, 17(1), 17-30.

\section{Introduction}

Financial performance provides an overview of financial information to the public or stakeholders on financial management achievements during a specific period. It is necessary to realize that the process of Islamic bank financial management is, of course, based on the conditions that have been determined in the Al-Quran because this is where the difference between conventional and Islamic banks is.

As a Muslim, the pillars of Islam must be believed and carried out. For that, as a Muslim, it is obligatory to pay zakat for capable Muslims. The size of the bank is able, if the bank is in profit. Profit is the company's target. If this condition is achieved, it shows that the bank is in a good performance. Zakat payments to the bank; its function is to clean up his wealth and report it in financial reports periodically. This is where the role of Islamic banks in realizing socio-economic justice is carried out. In conventional banks, usually, the zakat role is replaced by the ratio of earnings per share.

The results of research from Hameed (2004), show that the Islamicity Index can be used to measure the performance of Islamic banks comprehensively. With the index, the Islamicity Disclosure Index and the Islamicity Performance Index can be measured. The benefit of this index is to provide information on the financial performance of Islamic banks to interested parties. Among others: managers, government, creditors, investors, employees, consumers, and the wider community. Hameed's research object was at two banks in Malaysia, namely Bank Islam Malaysia Berhad and the Bahrain Islamic Bank.

One of the parties who need information on the performance/achievements of Islamic banks is the wider community, especially Muslims. This happens because the management of Islamic banks must be based on Islamic principles, so that performance measures also concern the performance of Islamic principles in financial management. In

18| IQTISHODUNA Vol. 17 (1), 2021

http://ejournal.uin-malang.ac.id/index.php/ekonomi 
addition, the consistency of the application of Islam in measuring the performance of Islamic banks is also awaiting information. This shows that Muslims' spiritual need for certainty in investing in sharia banks is critical, not only the value of the return on money invested in these banks. For the non-Muslim community, the information on this achievement is significant for knowing which Islamic bank has a good performance, for the choice of place to invest.

Performance measurement with the Islamicity Performance Index is applied to determine Islamic banks' financial performance, where stakeholders need this information as stakeholders. The index in the Islamicity Performance Index includes three main measures, namely adherence to the application of sharia principles, ways of managing companies, and social responsibility to the environment. This approach has six financial ratios, namely: profit sharing ratio, zakat perform performance ratio, equitable distribution ratio, directors-employee welfare ratio, Islamic investment VS non-Islamic investment ratio, Islamic income VS non-Islamic income.

Researchers are interested in researching Islamic Commercial Banks' object in Indonesia because after the issuance of Law No.21 of 2008 relating to Islamic banking, Islamic commercial banks are supposed to operate their activities with Islamic principles so that it is expected to be able to become a financial institution that can provide benefits to all people in Indonesia. Where the responsibility of this institution includes financial aspects and its contribution to the community/environment. The existence of social responsibility in this environment is what distinguishes between Islamic banks and conventional banks. However, in practice, the Bank's Performance Measurement is only based on management factors, so that the indicators of Islamic values are not considered. As a result, there is a lack of public trust in the Islamic values applied by Islamic Commercial Banks. This study aims to analyze the financial performance of Islamic Commercial Banks in Indonesia using the Islamicity Performance Index approach after the issuance of Law no. 21 of 2008.

This research is expected to have a theoretical contribution to provide scientific ideas for the development of Islamic accounting, financial management, and financial accounting. Besides, it has a practical contribution to provide information on the financial performance of Islamic commercial banks in Indonesia as a whole regarding aspects of sharia compliance, 
corporate governance, and social or environmental sensitivity to the government, investors, and other stakeholders. It provides information on which Islamic banks have been managed. Better, in terms of investment returns and contribution to the broader community.

\section{Literature Review}

\section{Financial Performance}

The company's performance is a signal of the company's performance over a certain period, as measured by financial analysis tools. Information on financial performance is essential. This will provide an overview of a company's financial condition regarding the good and bad financial conditions of the company. At this time, the changes that occur in the environment are very dynamic. To deal with this, it can be done by managing resources optimally. Mainly in dealing with business patterns in the era of the industrial revolution 4.0. Analysis of the company's financial management / financial performance achievements is essential to fostering public and investor confidence. Public trust in the company can show the value of the company. Performance is the effectiveness and efficiency of an organization or a manager in achieving predetermined goals (Stoner, 1996). The meaning of efficiency is the company's ability to produce optimal output with minimal resources. Effectiveness is the ability a company has to achieve goals in the right way. The company benefits from its performance appraisal, namely: measuring the company's performance in a certain period, to see the overall performance of the organization, the basis for determining future corporate strategy, consideration for decision making, and consideration for corporate investment decisions.

\section{IPI (Islamicity Performance Index)}

One way to measure financial performance is to use an index. Islamic Bank, its financial performance can also be measured by the Islamic Index. This is following the research of Hameed (2004), who developed an index called the Islamicity Performance Index. This measurement provides an overview not only of the bank's financial condition, but also provides information on compliance with the application of the Syariah value to the bank, which includes: the halalness of the transaction, both from the transaction method and the object or product being transacted Obligation to pay zakat. This is done as a form of cleansing against the bank's wealth. Then

20| IQTISHODUNA Vol. 17 (1), 2021

http://ejournal.uin-malang.ac.id/index.php/ekonomi 
distributed in the environment. Moreover, consistency in avoiding activities that contain elements of usury. The Islamic-based Performance Index has the following scope:

\section{Profit Sharing Ratio (PSR)}

This ratio describes the bank's ability to manage funds for both fundraising and fund distribution activities using a cooperation contract (Antonio, 2001). This contract consists of the mudharabah and musyarakah contracts. Mudharabah agreement is a cooperation between shohibul maal (owner of capital) and mudharib (manager of capital) (Nurhayati \& Wasilah, 2011). The musyarakah contract is a collaboration between capital owners. Both of these contracts are profit-sharing using revenue sharing and profit sharing techniques. The determination of the results received by both parties is determined in proportion to the ratio (Natalie et al., 2014). Profit-sharing is the goal targeted by Islamic banks.

PSR = (Mudharabah + Musyarakah) $/$ Total Financing

Zakat Performance Ratio (ZPI)

Zakat characterizes Sharia accounting. Zakat is one of the pillars of Islam, which must be believed and practiced for capable Muslims (Adityangga, 2006). Capable measure for the company, if the company has achieved profit. This means that the company's consistency is paying and reporting in the financial statements to be measured in the zakat performance ratio. Zakat is calculated based on profit before the pack is paid. The zakat is distributed among eight a snap. If the company's profit is high, more and more people can enjoy it from the zakat they pay. In Islamic banks, the role of zakat is usually measured by earnings per share.

ZPR = Zakat / Net Asset

\section{Equitable Distribution Ratio (EDR)}

The success of bank management in obtaining results must be distributed to the parties contributing to these successes. These parties are managers, investors, employees, creditors, government, and society (Ria \& Masiyah, 2018). For this reason, the distribution of results must be evenly distributed. This ratio is to measure how comparable the results of the company are to these parties.

EDR = Average Distribution For Each Stakeholder / Total Revenue

IQTISHODUNA Vol. 17 (1), $2021 \mid 21$

http://ejournal.uin-malang.ac.id/index.php/ekonomi 


\section{Directors-Employees Welfare Ratio (DEWR)}

Islam has taught that workers' wages must be given according to their contribution. In this case, the principle of justice must be applied. For this reason, the meaning of justice is the achievement of equal distribution of employees with the salary of the manager. This ratio is to measure the ratio of the director's salary to the welfare received by employees. Employee welfare consists of: salary, bonus, training, remuneration and so on.

DER = Average salary of directors / Average welfare of permanent employees.

\section{Islamic Investment vs Non-Islamic Investment}

Riba, gharar, and gambling are methods of obtaining profits that Islam prohibits. For this reason, Islamic banks need to explain the ways to manage funds invested by the public. Considering the performance measure like sharia is adherence to the application of Islamic values in Islamic banks, for this reason, the guarantee of the halalness of a transaction must be upheld. However, because Islamic banks cannot be separated from conventional managed institutions' transactions, Islamic banks also cannot escape from participating in transactions by investing in non-halal ones. This ratio assesses the ratio between banks' investments in a halal manner compared to all transactions made, both halal and haram investments.

$\mathrm{PH}=$ income $/$ (halal income + non-halal income)

\section{Islamic Income vc Non-Islamic Income}

Halal is a characteristic of transactions that Islamic banks must carry out. For this reason, the income received by the bank must also be ensured that it comes from a halal source. However, because the transaction made allows the bank to accept non-halal transactions, the bank must disclose the condition honestly. This ratio is used to measure the ratio between halal and non-halal income. Apart from that, it also reveals the amount, source of income, and how income is determined.

$\mathrm{IH}=$ Halal investment / (Halal investment / (Halal investment + non-halal investment)

\section{Sharia Commercial Bank}

According to article 1 in point 2 of Law no. 21 of 2008 that the existence of banks is to help improve the standard of living of the community by providing funds collection services in the form of savings, current accounts,

22| IQTISHODUNA Vol. 17 (1), 2021

http://ejournal.uin-malang.ac.id/index.php/ekonomi 
and deposits, as well as channeling funds in the form of credit or loan. Article 1 point 1 of Law no. 21 in 2008 describes business activities, methods, and mechanisms for implementing Sharia Banks and Sharia Business Units' activities and institutions. Whereas in point 7, it discusses sharia principles that Islamic banks carry out. Besides, it was also explained, that based on its type, banks include Sharia Commercial Banks and Sharia Rural Banks. Point 12 states that sharia principles are based on Islamic law / muamalah as operational banking guidelines based on fatwas issued by institutions that have the authority to determine fatwas in the field of Sharia. For operations, there are differences in objectives and functions between conventional and Islamic banking. Article 3 explains that Islamic banking's objective is to support the implementation of national development to achieve increased justice, togetherness, and equal distribution of welfare for the Indonesian people. Article 4 describes the role of Islamic banks in carrying out social functions, in the form of the Baitul Maal institution. This institution can receive zakat, infaq, alms, waqf, grants and zakat, but it must be distributed to the institution's zakat management institution. These activities are in addition to Islamic banks' main activities, namely raising funds and channeling funds. The procedures for implementing the social role of Islamic banks must be following the stipulated laws and regulations. The mechanism for implementing social functions must be following the provisions.

\section{Research methodology}

This research is a non-statistical descriptive quantitative research. This study is expected to provide an overview of Islamic banks' performance according to the Islamic Index Performance approach. Quantitative research is a study that uses data in the form of numbers.

\section{Research Result and Discussion}

Based on Table 1, it can be seen that there has been an increase in profit-sharing financing in the last nine years since the issuance of Law No. 21 of 2008 at Bank Syariah Mandiri, Bank Muamalah, BRI Syariah, BNI Syariah, Bank Mega Syariah and Bank Bukopin Syariah. Act Number 21 of 2008 concerning Sharia Banking regulates everything concerning Sharia Banks and Sharia Business Units, including institutions, business activities, and methods and processes for carrying out their business activities. It can be 
said that Islamic banks' performance is better at using the share of profit sharing rather than buying and selling. This can be seen in the portion of profit-sharing financing which tends to increase every year. Profit-sharing financing is a financing with a cooperation agreement between the bank as the shahibul maal and the customer as the mudarib. With profit sharing using a profit sharing system. This result or operating profit certainly determines the parties' results in collaboration with the predetermined profit proportion. This is following QS At-Taubah [9]: 105. This means: And say work you, then Allah and His Messenger and the believers will see your work, and you will returned to (Allah) Who Knows the unseen and the real, and $\mathrm{He}$ will tell you what you have done.

Table 1. Profit Sharing Ratio

\begin{tabular}{|c|c|c|c|c|c|c|c|c|c|c|}
\hline Bank & 2009 & 2010 & 2011 & 2012 & 2013 & 2014 & 2015 & 2016 & 2017 & 2018 \\
\hline $\begin{array}{l}\text { Bank } \\
\text { Mandiri }\end{array}$ & 39,07 & 35,02 & 59,93 & 62,47 & 65,94 & 45,67 & 35,95 & 34,75 & 35,56 & 37,45 \\
\hline $\begin{array}{l}\text { Bank Muamalah } \\
\text { Indonesia }\end{array}$ & 51,49 & 46,13 & 43,06 & 45,05 & 44 & 49,37 & 98,72 & 98,83 & 98,3 & 50,61 \\
\hline BRI Syariah & 29 & 23,69 & 46,88 & 64,48 & 80,76 & 100 & 31,28 & 36,08 & 40,85 & 83,08 \\
\hline BNI Syariah & 16,84 & 19,64 & 53,15 & 63,06 & 73,80 & 99,92 & 82,24 & 88,80 & 96,16 & 95,60 \\
\hline Bank Mega Syariah & 6,08 & 4,44 & 10,14 & 5,4 & 14,46 & 20,64 & 99,78 & 94,68 & 99,80 & 99,49 \\
\hline $\begin{array}{l}\text { Bank } \\
\text { Syariah }\end{array}$ & 25,26 & 33,6 & 33,96 & 31,70 & 33,22 & 38,64 & 59,79 & 54,31 & 49,88 & 50,60 \\
\hline
\end{tabular}

Table 2. Zakat Performance Ratio

\begin{tabular}{|c|c|c|c|c|c|c|c|c|c|c|}
\hline Bank & 2009 & 2010 & 2011 & 2012 & 2013 & 2014 & 2015 & 2016 & 2017 & 2018 \\
\hline $\begin{array}{ll}\text { Bank } & \text { Syariah } \\
\text { Mandiri } & \end{array}$ & 0,084 & 0,053 & 0,09 & 0,09 & 0,09 & 0,03 & 0,4 & 0,5 & 0,7 & 1,03 \\
\hline $\begin{array}{l}\text { Bank Muamalah } \\
\text { Indonesia }\end{array}$ & 0,037 & 0,007 & 0,02 & 0,02 & 0,03 & 0,04 & 0,06 & 0,36 & 0,4 & 0,22 \\
\hline BRI Syariah & 0,011 & 0,005 & 0,02 & 0,03 & 0,027 & 0,042 & 0,043 & 1,75 & 1,95 & 3,9 \\
\hline BNI Syariah & 0,23 & 0,31 & 0,37 & 0,35 & 5,24 & 5,4 & 3,39 & 2,75 & 4,47 & 3,9 \\
\hline Bank Mega Syariah & 0,065 & 0,066 & 0,098 & 0,07 & 0,07 & 0,04 & 0,510 & 0,49 & 0,556 & 0,46 \\
\hline $\begin{array}{ll}\text { Bank } & \text { Bukopin } \\
\text { Syariah } & \end{array}$ & 0 & 0 & 0 & 0 & 0 & 0 & 0 & 0 & 0 & 0 \\
\hline
\end{tabular}

Based on this ratio and the increase in wealth, it seems that Islamic banks do not increase the payment of zakat. This is certainly not in accordance with the characteristics of the tazkiyah. Tazkiyah is an essential thing, because zakat in real terms, is a process of purifying oneself from the owner of the wealth. It means that by paying zakat, the wealthy owner is cleansed from

24| IQTISHODUNA Vol. 17 (1), 2021 http://ejournal.uin-malang.ac.id/index.php/ekonomi 
greed, stingy and individual nature. Indeed, overall the zakat paid by Islamic banking in Indonesia is not good enough. These results support the research of Sabirin (2018); Ria \& Masiyah (2018). Even the six Bank Bukopin Islamic banks as Islamic financial institutions have never paid zakat at all.

The word zakat is the root word for zakat which means blessing, growing, and being good. According to oral al Arabic, the word zakat means holy, growing, blessing, and praiseworthy. Zakat, according to the term fiqh, is a certain amount of assets that must be submitted to people who are entitled according to the sharia of Allah SWT. The word zakat in the terminology of the Qur'an is equivalent to the word shadaqah.

Islamic banks' performance must be based on zakat payments by banks to replace conventional performance indicators, namely earnings per share. With the zakat performance ratio, zakat performance can be measured by how much Islamic banks distribute zakat from net assets (net assets). This is following QS Al-Baqarah [2]: 43. Meaning: And establish prayers, pay zakat and bow along with those who bow.

Net worth is a bank asset that is free of debt. This means that the greater the net worth, ideally the bigger the bank distributes zakat. According to PSAK 101, zakat management activities are presented in the Islamic financial statements' zakat funds report. The presentation of information on the management of zakat funds is a form of concern for the Islamic entity in fulfilling its social obligations to the community. This shows that Islamic banks do not only carry out their business activities, but also carry out sharia activities, namely distributing zakat to those who are entitled to receive them.

Table 3. Equitable Distribution Ratio PT. BANK MUAMALAT

\begin{tabular}{|c|c|c|c|c|c|c|c|c|c|c|}
\hline Ratio & 2009 & 2010 & 2011 & 2012 & 2013 & 2014 & 2015 & 2016 & 2017 & 2018 \\
\hline $\begin{array}{l}\text { Qard and } \\
\text { Donation }\end{array}$ & 38,12 & 112,17 & 136,88 & 70,52 & 19,7 & 3,38 & 10,05 & 3,34 & 19,57 & 13,36 \\
\hline $\begin{array}{l}\text { Employess } \\
\text { Ecxpense }\end{array}$ & 24,61 & 23,85 & 29 & 30,12 & 1,47 & 4,89 & 3,570 & 2,73 & 2,499 & 14,95 \\
\hline Shareholders & 0 & 0 & 0,001 & 0,004 & 0,011 & 0,099 & 0,0001 & 0,012 & 0,092 & 0 \\
\hline Net Profit & 6,14 & 16,09 & 19,33 & 21,45 & 19,67 & 1,56 & 3,24 & 21,45 & 0,71 & 8,11 \\
\hline
\end{tabular}


Naning Fatmawatie

Table 4. Equitable Distribution Ratio PT. BANK SYARIAH MANDIRI

\begin{tabular}{|c|c|c|c|c|c|c|c|c|c|c|}
\hline Ratio & 2009 & 2010 & 2011 & 2012 & 2013 & 2014 & 2015 & 2016 & 2017 & 2018 \\
\hline $\begin{array}{l}\text { Qard and } \\
\text { Donation }\end{array}$ & 76,88 & 112,17 & 136,88 & 70,52 & 17,43 & 58,3 & 45,6 & 43,4 & 16,29 & 22,4 \\
\hline $\begin{array}{l}\text { Employess } \\
\text { Ecxpense }\end{array}$ & 28,78 & 31 & 33,78 & 27,1 & 27,76 & 18,9 & 37,1 & 45,4 & 23,7 & 33,2 \\
\hline Shareholders & 0,57 & 0,62 & 0,63 & 0,69 & 0,75 & 0,71 & 0,51 & 0,71 & 0,14 & 0,12 \\
\hline Net Profit & 21,19 & 20,84 & 19,29 & 22,44 & 15,16 & 11,42 & 51,81 & 71,99 & 22,80 & 44,1 \\
\hline
\end{tabular}

Table 5. Equitable Distribution Ratio PT. BANK BRI Syariah

\begin{tabular}{|c|c|c|c|c|c|c|c|c|c|c|}
\hline Ratio & 2009 & 2010 & 2011 & 2012 & 2013 & 2014 & 2015 & 2016 & 2017 & 2018 \\
\hline $\begin{array}{l}\text { Qard } \\
\text { Donation }\end{array}$ & 46,96 & 61,67 & 89,38 & 52,26 & 90,29 & 23,2 & 15,51 & 10,51 & 26,98 & 41,92 \\
\hline $\begin{array}{l}\text { Employess } \\
\text { Ecxpense }\end{array}$ & $\begin{array}{l}52 \\
29\end{array}$ & 42,29 & 44,85 & 34,38 & 38,08 & 12,68 & 11,57 & 10,87 & 14,94 & 27,32 \\
\hline Shareholders & 0,01 & 0,80 & 0,22 & 0,25 & 0,18 & 0,37 & 0,139 & 0,17 & 0,14 & 0 \\
\hline Net Profit & 9,4 & 2,44 & 1,73 & 10,83 & 12,33 & 1,208 & 4,763 & 6,013 & 5,204 & 5,7 \\
\hline
\end{tabular}

Table 6. Equitable Distribution Ratio PT. BNI Syariah

\begin{tabular}{lllllllllll}
\hline Ratio & $\mathbf{2 0 0 9}$ & $\mathbf{2 0 1 0}$ & $\mathbf{2 0 1 1}$ & $\mathbf{2 0 1 2}$ & $\mathbf{2 0 1 3}$ & $\mathbf{2 0 1 4}$ & $\mathbf{2 0 1 5}$ & $\mathbf{2 0 1 6}$ & $\mathbf{2 0 1 7}$ & $\mathbf{2 0 1 8}$ \\
& & & & & & & & & & \\
\hline $\begin{array}{l}\text { Qard and Donation } \\
\text { Employess }\end{array}$ & 34,23 & 42.33 & 37,65 & 35,73 & 41,75 & 61,95 & 27,75 & 28,74 & 45,87 & 11,25 \\
$\begin{array}{l}\text { Ecxpense } \\
\text { Shareholders }\end{array}$ & 45,7 & 57,4 & 54,6 & 50,2 & 41,34 & 50,62 & 14,55 & 10,28 & 22,21 & 25,03 \\
Net Profit & 0 & 0 & 0 & 0 & 0,7 & 0,42 & 0,37 & 0,30 & 0,14 & 0 \\
\end{tabular}

Table 7. Equitable Distribution Ratio PT. BANK MEGA Syariah

\begin{tabular}{lllllllllll}
\hline Ratio & $\mathbf{2 0 0 9}$ & $\mathbf{2 0 1 0}$ & $\mathbf{2 0 1 1}$ & $\mathbf{2 0 1 2}$ & $\mathbf{2 0 1 3}$ & $\mathbf{2 0 1 4}$ & $\mathbf{2 0 1 5}$ & $\mathbf{2 0 1 6}$ & $\mathbf{2 0 1 7}$ & $\mathbf{2 0 1 8}$ \\
& & & & & & & & & & \\
\hline $\begin{array}{l}\text { Qard and Donation } \\
\text { Employess }\end{array}$ & 23,67 & 8,79 & 15,22 & 27,39 & 20,35 & 0,048 & 0,21 & 0,107 & 0,048 & 0,01 \\
$\begin{array}{l}\text { Ecxpense } \\
\text { Shareholders }\end{array}$ & 35 & 37,14 & 38,02 & 30,59 & 27,96 & 46,42 & 43,65 & 16,83 & 58,49 & 36,82 \\
Net Profit & 11,48 & 8,25 & 6,7 & 17,66 & 11,63 & 1,33 & 0,29 & 1,38 & 8,71 & 2,106 \\
\hline
\end{tabular}

26| IQTISHODUNA Vol. 17 (1), 2021

http://ejournal.uin-malang.ac.id/index.php/ekonomi 
Implementation of The Islamicity Performance.....

Table 8. Equitable Distribution Ratio PT. BANK BUKOPIN Syariah

\begin{tabular}{lllllllllll}
\hline Ratio & $\mathbf{2 0 0 9}$ & $\mathbf{2 0 1 0}$ & $\mathbf{2 0 1 1}$ & $\mathbf{2 0 1 2}$ & $\mathbf{2 0 1 3}$ & $\mathbf{2 0 1 4}$ & $\mathbf{2 0 1 5}$ & $\mathbf{2 0 1 6}$ & $\mathbf{2 0 1 7}$ & $\mathbf{2 0 1 8}$ \\
& & & & & & & & & & \\
\hline $\begin{array}{l}\text { Qard and Donation } \\
\text { Employess }\end{array}$ & 0 & 0 & 1,07 & 0,75 & 0,87 & 0,21 & 0,24 & 0,26 & 0,36 & 0,43 \\
$\begin{array}{l}\text { Ecxpense } \\
\text { Shareholders }\end{array}$ & 0 & 0 & 0 & 0 & 0 & 0 & 0,48 & 0,31 & 0 & 0 \\
Net Profit & 2,96 & 17,8 & 18,2 & 18,7 & 15,2 & 23,3 & 21,4 & 13,1 & 10,34 & 12,45 \\
\hline
\end{tabular}

The Equitable Distribution Ratio (EDR) shows that Islamic banks must uphold the principle of helping others, including employees, customers, and the general public. When referring to the theory of Islamic distribution, according to Antonio, basically Islam has two central distribution systems, namely commercial distribution and following market mechanisms and distribution systems that are based on aspects of social justice. The first distribution system, commercial in nature, proceeds through an economical process. According to Qardhawi (2001), there are four aspects related to fair distribution, namely: 1) equal salary for workers; 2) profit or profit for the party running the business or trading through the profit-sharing mechanism; 3 ) the cost of renting land and other means of production; 4) government responsibilities related to regulations and policies. The second system is a system with a social dimension, namely distributing income to people who cannot be involved in the economic process in the form of zakat, donations, and alms.

Table 9. Directors-Employees Welfare Ratio

\begin{tabular}{|c|c|c|c|c|c|c|c|c|c|c|}
\hline Bank & 2009 & 2010 & 2011 & 2012 & 2013 & 2014 & 2015 & 2016 & 2017 & 2018 \\
\hline $\begin{array}{l}\text { Bank } \\
\text { Mandiri }\end{array}$ & 9 & 12 & 31,81 & 49,36 & 47,81 & 43,81 & 12,16 & 6,18 & 6,17 & 6,05 \\
\hline $\begin{array}{l}\text { Bank Muamalah } \\
\text { Indonesia }\end{array}$ & 57 & 25 & 25,37 & 26,78 & 28,84 & 32,97 & 12,5 & 15,64 & 9,03 & 12,05 \\
\hline BRI Syariah & 0,17 & 2 & 19,16 & 21,58 & 38,52 & 33,59 & 9,26 & 2,88 & 2,52 & 3,01 \\
\hline BNI Syariah & 2,2 & 2,5 & 8,68 & 6,04 & 12,02 & 11,18 & 14,23 & 19.95 & 29,91 & 20,01 \\
\hline Bank Mega Syariah & 13 & 11 & 25,93 & 21,85 & 25,78 & 29,58 & 25,4 & 24,5 & 25.4 & 29,5 \\
\hline $\begin{array}{l}\text { Bank } \quad \text { Bukopin } \\
\text { Syariah }\end{array}$ & 0 & 0 & 9,85 & 12,50 & 18,40 & 14,53 & 8,4 & 8,07 & 7,83 & 8,90 \\
\hline
\end{tabular}

Based on the Table 9, it can be seen that the Directors-Employess Ratio (DER) of the six banks tends to fluctuate. This result is not in accordance with the research of Sabirin (2018). This shows that the banking sector has

IQTISHODUNA Vol. 17 (1), $2021 \mid 27$

http://ejournal.uin-malang.ac.id/index.php/ekonomi 
fluctuated in the amount of expenditure on director salaries and employee salaries every year. Of course, this is influenced by the size of the salary burden issued by Islamic banking according to both director's and employees' salaries.

Welfare is a total remuneration (material and non-material) provided by the company at the discretion. The goal is to maintain and improve the physical and mental condition of employees so that productivity increases. Welfare can be viewed as additional assistance money to employees. Especially the payment to them. With a sufficient level of welfare, they will be calmer in carrying out their duties. With this calm, it is hoped that employees will be more disciplined. This indicator explains the comparison between the welfare of directors and employees. Many claims that directors earn significantly more than their performance. The goal is to measure whether directors get a much higher salary than employees. Employee welfare includes salary, training, and others.

Table 10 shows that the value of Islamic Income VS Non-Islamic Income for nine years in the six Islamic banks has increased. These results support the research of Sebtianita (2015) and Sabirin (2018). This means that Islamic banks' revenue is mostly or almost entirely of income originating from Syar'i transactions. Income or return, in everyday language, is called the rate of return or return on capital (ma'ad). This is based on QS. An-Nisa '[4]: 9. Meaning: "And fear Allah those who should leave behind them weak children, whom they worry about (their welfare). Therefore let them fear Allah, and let them speak the right word.

Income is the result obtained by the bank from its activities in managing productive assets. However, in addition to obtaining income from productive assets, Islamic banks also receive income from conventional banks. Income at this conventional bank generates income from non-halal services in the form of interest that is recorded in the benevolence fund report on the financial statements of Islamic banks. Non-halal income occurs because Islamic banks still need a relationship with conventional banks. After all, in the financial system, it cannot be managed by Islamic banks, so that their status is an emergency. If in the future Islamic banks can serve these transactions, it is recommended that the relationship with conventional banks be immediately terminated to avoid ribawi transactions.

28| IQTISHODUNA Vol. 17 (1), 2021

http://ejournal.uin-malang.ac.id/index.php/ekonomi 
Implementation of The Islamicity Performance.....

Table 10. Islamic Income vs Non Islamic Income

\begin{tabular}{|c|c|c|c|c|c|c|c|c|c|c|}
\hline Bank & 2009 & 2010 & 2011 & 2012 & 2013 & 2014 & 2015 & 2016 & 2017 & 2018 \\
\hline $\begin{array}{l}\text { Bank } \\
\text { Mandiri }\end{array}$ & 99,88 & 99,98 & 99,98 & 99,99 & 99,98 & 99,98 & 99,99 & 99,99 & 99,99 & 99,99 \\
\hline $\begin{array}{l}\text { Bank Muamalah } \\
\text { Indonesia }\end{array}$ & 99,96 & 99,97 & 100 & 100 & 99,98 & 99,97 & 99,93 & 99,96 & 99,79 & 99,99 \\
\hline BRI Syariah & 99,94 & 99,99 & 99,99 & 99,99 & 99,99 & 99,99 & 99,99 & 99,99 & 99,97 & 99,99 \\
\hline BNI Syariah & 99,78 & 99,85 & 99,93 & 99,97 & 99,99 & 100 & 99,99 & 99,98 & 99,99 & 99,99 \\
\hline $\begin{array}{l}\text { Bank } \\
\text { Syariah }\end{array}$ & 100 & 100 & 100 & 99,93 & 99,96 & 99,97 & 99,98 & 99,99 & 99,97 & 99,99 \\
\hline Bank Mega Syariah & 99,92 & 99,97 & 99,99 & 99,99 & 99,99 & 99,99 & 99,99 & 99,96 & 99,98 & 99,99 \\
\hline
\end{tabular}

This indicator explains the comparison between halal income and all income earned by Islamic banks (halal and non-halal income). This is following QS. Al-Baqarah [2]: 278. This means: "O you who believe, fear Allah and leave the remaining usury (which has not been collected) if you are believers" also QS. Al-Baqarah [2]: 279. Meaning: "So if you do not do (leaving the remaining usury), then know that Allah and His Messenger will fight against you. And if you repent (from taking usury), then you are the principal of your wealth; you are neither persecuted nor (nor) persecuted ". The resulting value is a measure of the halalness and success of implementing Islamic banks' basic principles, namely being free from the element of usury in terms of income.

\section{Conclusion}

Islamic banks' performance is based on the Islamic Performance Index (IPI) that: Profit Sharing Ratio (PSR) tends to increase. The best PSR is Bank Mega Syariah. However, the Zakat Performace Ratio (ZPR) tends to be small. The worst ZPR is Bank Bukopin Syariah and the best is BNI Syariah. For Equitable Distribution ratio (EDR), the best Qard is BRI Syariah. For EDR Employees the best is Bank Mega Syariah. For EDR Dividend the best is BSM . The best EDR net profit is BSM. As for the Directors-Employee Welfare Ratio, the best is Bank Mega Syariah. For Islamic Income VS Non-Islamic Income, everything is very good.

The implication of this research is to contribute to Islamic banking, and it is hoped that more evaluating its performance, especially for the Zakat Performance Ratio, should be further improved. Given the importance of charity benefits for society's welfare, especially eight a snap, so that the role of Islamic social banks will be even better. For further researchers, it is also 
expected to analyze Islamic financial institutions other than Islamic banks using the Islamic Performance Index (IPI) analysis.

\section{Reference}

Adityangga, K. (2006). Membumikan Ekonomi Islam. Jakarta: Pilar Media.

Antonio, M. S. (2001). Bank Syariah: Dari Teori ke Praktik Depok: Gema Insani dan Tazkia Cendekia.

Hameed, S. (2004). Alternative Disclosure \& Performance Measures For Islamic Banks dalam Proceeding of The Second Conference on Administrative Science : Meeting The Challenges of The Globalization Age. Dahran, Saudi Arabia.

Law No. 21 of 2008. https://www.ojk.go.id/waspadainvestasi/id/regulasi/Documents/UU_No_21_Tahun_2008_Perbankan_ Syariah.pdf

Natalia, E., Dzulkirom, M. A., \& Mangesti, S. R. (2014). Pengaruh Tingkat Bagi Hasil Deposito bank Syariah dan Suku Bunga Deposito bank Umum Terhadap Jumlah Simpanan Deposito Mudharabah. Jurnal Administrasi Bisnis, 9(1), 1-7.

Nurhayati, S., \& Wasilah. (2011). Akuntansi Syariah di Indonesia. Jakarta: Salemba Empat

Ria, F. \& Masiyah, K, (2018). Analisis Kinerja Keuangan Perbankan Syariah Dengan Pendekatan Islamicity Performance Index Pada Perbankan Syariah Di Indonesia, Jurnal Akademik Akuntansi, 1(11), 74-83.

Sabirin, (2018). Analisis Kinerja Perbankan Syariah Di Indonesia Dengan Menggunakan Pendekatan Islamicity Performance Index dan Islamic Corporate Governance, al maslahah, 14(2).

Sebtianita, E. (2015). Analisis Kinerja Bank Umum Syariah Dengan Menggunakan Pendekatan Islamicity Performance Index (Studi Pada Bank Umum Syariah Periode Tahun 2009-2013). Jurnal El-Dinar, 3(1), 109-117.

Stoner. (1996). Manajemen Edisi Bahasa Indonesia, Jakarta: Prenhallindo. Qardawi Y. (2001). Peran Nilai dan Moral dalam Perekonomian Islam. Jakarta: Robbani Press.

30 | IQTISHODUNA Vol. 17 (1), 2021 http://ejournal.uin-malang.ac.id/index.php/ekonomi 